
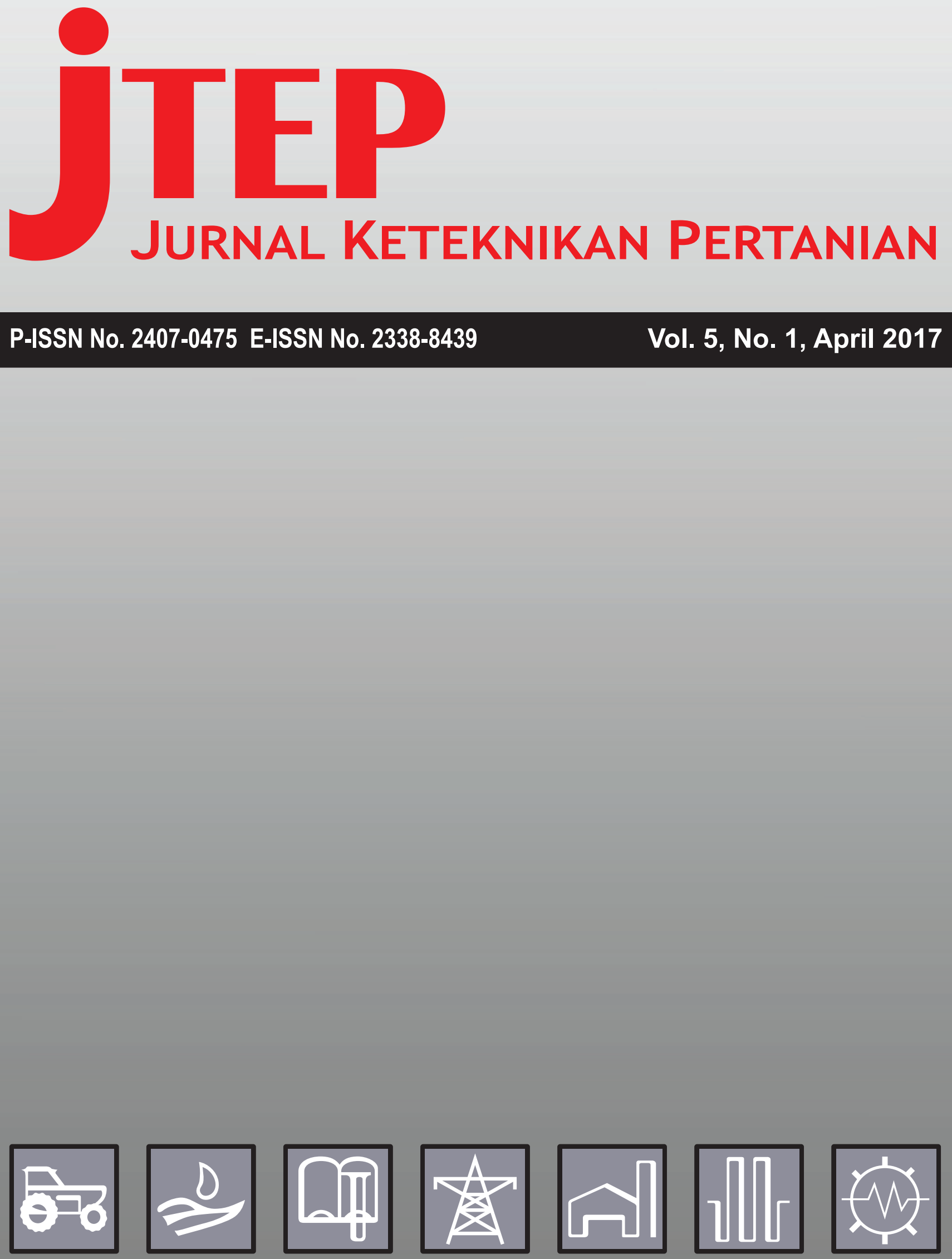

Publikasi Resmi
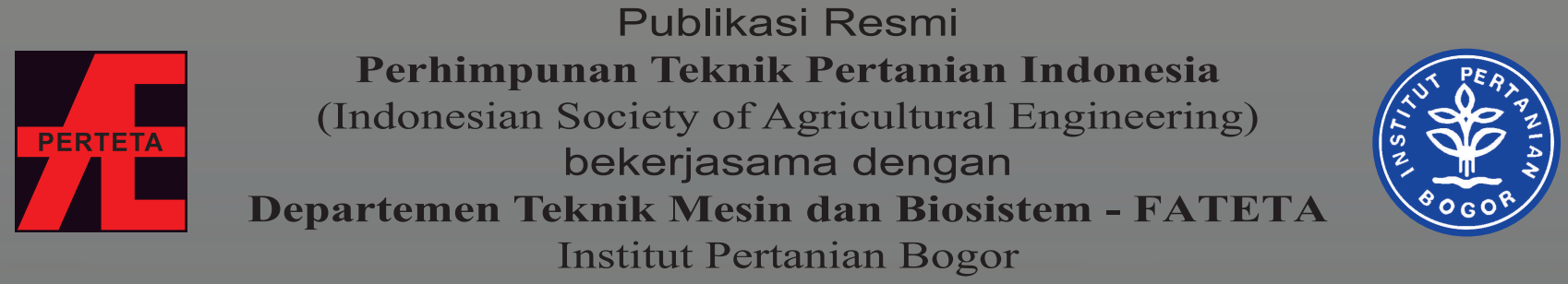


\title{
jteP JURnal Keteknikan Pertanian
}

\author{
P-ISSN 2407-0475 E-ISSN 2338-8439 \\ Vol. 5, No. 1, April 2017
}

Jurnal Keteknikan Pertanian (JTEP) terakreditasi berdasarkan SK Dirjen Penguatan Riset dan Pengembangan Kementerian Ristek Dikti Nomor I/E/KPT/2015 tanggal 21 September 2015. Selain itu, JTEP juga telah terdaftar pada Crossref dan telah memiliki Digital Object Identifier (DOI) dan telah terindeks pada ISJD, IPI, Google Scholar dan DOAJ. JTEP terbit tiga kali setahun yaitu pada bulan April, Agustus dan Desember berisi 12 naskah untuk setiap monuron baik dalam edisi cetak maupun edisi online. Jurnal berkala ilmiah ini berkiprah dalam pengembangan ilmu keteknikan untuk pertanian tropika dan lingkungan hayati. Penulis makalah tidak dibatasi pada anggota PERTETA tetapi terbuka bagi masyarakat umum. Lingkup makalah, antara lain: teknik sumberdaya lahan dan air, alat dan mesin budidaya pertanian, lingkungan dan bangunan pertanian, energi alternatif dan elektrifikasi, ergonomika dan elektronika pertanian, teknik pengolahan pangan dan hasil pertanian, manajemen dan sistem informasi pertanian. Makalah dikelompokkan dalam invited paper yang menyajikan isu aktual nasional dan internasional, review perkembangan penelitian, atau penerapan ilmu dan teknologi, technical paper hasil penelitian, penerapan, atau diseminasi, serta research methodology berkaitan pengembangan modul, metode, prosedur, program aplikasi, dan lain sebagainya. Penulisan naskah harus mengikuti panduan penulisan seperti tercantum pada website dan naskah dikirim secara elektronik (online submission) melalui http:// journal.ipb.ac.id/index.php/jtep.

\section{Penanggungjawab:}

Ketua Perhimpunan Teknik Pertanian Indonesia

Ketua Departemen Teknik Mesin dan Biosistem, Fakultas Teknologi Pertanian,IPB

\section{Dewan Redaksi:}

Ketua : Wawan Hermawan (Scopus ID: 6602716827, Institut Pertanian Bogor)

Anggota : Asep Sapei (Institut Pertanian Bogor)

Kudang Boro Seminar (Scopus ID: 54897890200, Institut Pertanian Bogor)

Daniel Saputra (Scopus ID: 6507392012, Universitas Sriwijaya - Palembang)

Bambang Purwantana (Universitas Gadjah Mada - Yogyakarta)

Yohanes Aris Purwanto (Scopus ID: 6506369700, Institut Pertanian Bogor)

Muhammad Faiz Syuaib (Scopus ID: 55368844900, Institut Pertanian Bogor)

Salengke (Scopus ID: 6507093353, Universitas Hasanuddin - Makasar)

I Made Anom Sutrisna Wijaya (Scopus ID: 56530783200, Universitas Udayana - Bali)

\section{Redaksi Pelaksana:}

Ketua : Rokhani Hasbullah (Scopus ID: 55782905900, Institut Pertanian Bogor)

Sekretaris : Lenny Saulia (Scopus ID: 16744818700, Institut Pertanian Bogor)

Bendahara : Hanim Zuhrotul Amanah (Universitas Gadjah Mada - Yogyakarta)

Anggota : Dyah Wulandani (Scopus ID: 1883926600, Institut Pertanian Bogor)

Usman Ahmad (Scopus ID: 55947981500, Institut Pertanian Bogor)

Satyanto Krido Saptomo (Scopus ID: 6507219391, Institut Pertanian Bogor)

Slamet Widodo (Scopus ID: 22636442900, Institut Pertanian Bogor)

Liyantono (Scopus ID: 54906200300, Institut Pertanian Bogor)

Administrasi : Diana Nursolehat (Institut Pertanian Bogor)

Penerbit: Perhimpunan Teknik Pertanian Indonesia (PERTETA) bekerjasama dengan

Departemen Teknik Mesin dan Biosistem, Institut Pertanian Bogor.

Alamat: Jurnal Keteknikan Pertanian, Departemen Teknik Mesin dan Biosistem,

Fakultas Teknologi Pertanian, Kampus Institut Pertanian Bogor, Darmaga, Bogor 16680.

Telp. 0251-8624 503, Fax 0251-8623 026,

E-mail: jtep@ipb.ac.id atau jurnaltep@yahoo.com

Website: web.ipb.ac.id/ jtep atau http://journal.ipb.ac.id/index.php/jtep

Rekening: BRI, KCP-IPB, No.0595-01-003461-50-9 a/n: Jurnal Keteknikan Pertanian

Percetakan: PT. Binakerta Makmur Saputra, Jakarta 


\section{Ucapan Terima Kasih}

Redaksi Jurnal Keteknikan Pertanian mengucapkan terima kasih kepada para Mitra Bebestari yang telah menelaan (me-review) Naskah pada penerbitan Vol. 5 No. 1 April 2017. Ucapan terima kasih disampaikan kepada: Dr.Ir. Lady Corrie Ch. Emma Lengkey, M.Si (Fakultas Pertanian, Universitas Sam Ratulangi), Dr.Ir. Andasuryani, S.TP, M.Si (Fakultas Teknologi Pertanian, Universitas Andalas), Dr. Rudiati Evi Masithoh, STP, M.Dev.Tech (Jurusan Teknik Pertanian, Universitas Gadjah Mada), Prof. Dr.Ir. Bambang Purwantana, MS (Jurusan Teknik Pertanian, Universitas Gadjah Mada), Prof.Ir. I Made Supartha Utama, MS., Ph.D (Fakultas Teknologi Pertanian, Universitas Udayana), Prof.Dr.Ir. Sutrisno, M.Agr (Departemen Teknik Mesin dan Biosistem, Institut Pertanian Bogor), Dr. Sri Rahayoe, STP., MP (Jurusan Teknik Pertanian, Universitas Gadjah Mada), Dr. Joko Nugroho Wahyu Karyadi. M.Eng (Jurusan Teknik Pertanian, Universitas Gadjah Mada), Prof.Dr.Ir. Lilik Sutiarso, M.Eng (Jurusan Teknik Pertanian, Universitas Gadjah Mada), Dr.Ir. Abdul Rozaq, DAA (Jurusan Teknik Pertanian, Universitas Gadjah Mada), Dr.Ir. I Wayan Budiastra, M.Agr (Departemen Teknik Mesin dan Biosistem, Institut Pertanian Bogor), Dr. Diding Suhandy, STP.,M.Agr (Fakultas Pertanian, Universitas Lampung), Ir. Moh. Agita Tjandra, M.Sc, Ph.D (Fakultas Teknologi Pertanian, Universitas Andalas), Dr. Ir. Sitti Nur Faridah, MP (Jurusan Teknologi Pertanian, Universitas Hasanuddin), Prof.Dr.Ir. Budi Indra Setiawan, M.Agr (Departemen Teknik Sipil dan Lingkungan, Institut Pertanian Bogor), Dr. Suhardi, STP., MP (Jurusan Teknologi Pertanian, Universitas Hasanuddin), Dr.Ir. Hadi K. Purwadaria, M.Sc (Departemen Teknik Mesin dan Biosistem, Institut Pertanian Bogor). 


\title{
Penggunaan Vis-NIR untuk Deteksi Serangan Huanglongbing pada Daun Jeruk
}

\section{The use of Vis-NIR for Detecting Huanglongbing Disease on Leaves of Citrus Orchard}

\author{
Raden Arief Firmansyah, Departemen Teknik Mesin dan Biosistem, \\ Program Studi Teknik Mesin Pertanian dan Pangan. Email: firmansyah.rief@gmail.com \\ Kudang Boro Seminar, Departemen Teknik Mesin dan Biosistem, Institut Pertanian Bogor. \\ Email: kseminar@apps.ipb.ac.id \\ Widodo, Departemen Proksi Tanaman, Institut Pertanian Bogor. Email: taniutun@gmail.com
}

\begin{abstract}
Huanglongbing is citrus disease which is a major threat for citrus orchard. Neither disease has a cure nor an efficient means of control. Early detection is important to prevent development and spread of the disease. The most effective detection used DNA test by PCR. However, identification used DNA test required sample preparation, time-consuming and expensive. The objective of this study was to build detection of healthy and $H L B$-infected leaves software. The leaf samples collected from citrus orchard in Situgede village, Bogor. Sample leaves divided into three group, Huanglongbing-infected leaves, healthy leaves and asymptomatic leaves. All samples was tested by PCR for verification visual symptoms of huanglongbing. Vis-NIR spectrometer with a spectra range of 339 to $1022 \mathrm{~nm}$ was used to acquisition HLB-infected and healthy leaves spectral data. MSC, SNV, baseline correction, first and second derivative were used for pretreatment method. Artificial neural network was used to build classification model. X-loading plot from principal component analysis was used to obtain sensitive wavelength. Classification for healthy and HLB-infected classs used sensitive wavelength baseline correction-based had the best performance and high accuracy (100\%). The classification model was embedded in software PC-desktop based which was used visual basic programming language. Asymptomatic leaves spectral from HLB-positive tree were used to testing classification model. Model classified data into HLB-infected group, which was consistent with PCR test. The result from this study indicated that developed software could be used to HLB detection in early stage of disease.
\end{abstract}

Keywords: huanglongbing, visible-near infrared spectroscopy, artificial neural network, citrus

\begin{abstract}
Abstrak
Huanglongbing adalah penyakit jeruk yang merupakan ancaman utama bagi budidaya jeruk. Tidak ada pengendalian yang tepat untuk Huanglongbing. Deteksi dini penting untuk mencegah penyebaran dan pengembangan penyakit ini. Deteksi dini yang paling efektif menggunakan tes DNA dengan PCR. Namun, identifikasi menggunakan tes DNA memerlukan persiapan sampel, memakan waktu dan mahal. Tujuan dari penelitian ini adalah membangun perangkat lunak deteksi daun sehat dan terinfeksi HLB. Sampel daun dikumpulkan dari kebun jeruk di Desa Situ Gede, Bogor. Sampel daun dibagi menjadi tiga kelompok, daun yang terinfeksi HLB, daun sehat dan daun belum bergejala. Semua sampel telah diuji dengan PCR untuk verifikasi gejala visual Huanglongbing. Spektrometer Vis-NIR dengan rentang spektrum dari 339-1022nm digunakan untuk mengumpulkan data spektrum daun terinfeksi HLB dan sehat. MSC, SVN, baseline correction, turunan pertama dan kedua dari spektra digunakan sebagai metode praperlakuan. Jaringan syaraf tiruan digunakan untuk membangun model klasifikasi Plot X-loading dari analisis komponen utama digunakan untuk mendapatkan panjang gelombang sensitif. Klasifikasi terhadap kategori daun sehat dan sakit menggunakan panjang gelombang sensitif berbasis baseline correction memiliki nilai akurasi $100 \%$ dan kinerja terbaik. Model klasifikasi yang ditanam pada perangkat lunak berbasis komputer desktop menggunakan bahasa pemrograman visual basic. Data spektrum daun belum bergejala dari pohon positif terinfeksi HLB digunakan untuk menguji model klasifikasi. Model mengklasifikasikan data tersebut ke kelompok terinfeksi HLB, yang konsinten dengan hasil pengujian PCR yang juga mengelompokkan pada daun terinfeksi HLB. Hasil penelitian ini menunjukkan bahwa perangkat lunak dapat digunakan untuk deteksi HLB pada tahap awal perkembangan penyakit.
\end{abstract}

Keywords: huanglongbing, visible-near infrared spectroscopy, artificial neural network, citrus 


\section{Latar Belakang}

Huanglongbing atau citrus greening termasuk penyakit berbahaya bagi budidaya jeruk. Di Indonesia, penyakit tersebut telah membunuh 2000ha kebun jeruk dalam jangka waktu 6 bulan dengan nilai kerugian Rp 120 miliar/tahun (Nurhadi 2015). Penyakit ini memiliki gejala yang mirip penyakit kekurangan zat hara sehingga sulit dibedakan. Karakteristik gejala penyakit ini adalah pucuk daun menguning dan blotchy mottle tetapi gejala tersebut terkadang bias dengan gejala lain yang muncul (Bove et al. 2006). Selain itu, terdapat akumulasi pati pada jaringan parenkima daun yang terinfeksi HLB (Schneider 1968). Di Asia, penyakit ini disebabkan oleh bakteri Candidatus liberactus asiaticum (Bove et al. 2006) yang penyebarannya dibantu oleh serangga Diaphorina citri (Taufik et al. 2010). Metode PCR (Polymer chain reaction) adalah metode berbasis DNA yang efektif untuk deteksi HLB (Iftikhar et al. 2016). Walaupun metode tersebut memberikan hasil akurat, biaya mahal dan proses pengujian yang butuh waktu menjadi kelemahan metode tersebut (Mishra et al. 2012; Pourreza et al. 2014). Oleh karena itu, dikembangkan metode alternatif yang bersifat cepat dan murah tetapi efektif mendeteksi HLB, antara lain menggunakan spektrosokopi fluorescence (Sankaran and Ehsani 2012), spektrosokopi inframerah (Cardinali et al. 2012), spektrosokopi Vis-NIR (Sankaran et al. 2011; Sankaran dan Ehsani 2011; Mishra et al. 2012), spektrosokopi MIR (Sankaran et al. 2010), Pencitraan dengan Vis-NIR dan termal (Sankaran et al. 2013), pencitntraan secara mikroskop (Kim et al. 2009) dan pencintraan dengan filter polarisasi (Pourreza et al. 2014). Di Indonesia, teknologi deteksi HLB selain PCR menggunakan LAMP (Loop-mediated isothermal amplification) yang dikembangkan oleh Balitjestro (Badan Penelitian Jeruk dan Buah Subtropika).

Pengendalian terhadap penyakit ini belum efektif, sehingga deteksi dini terhadap gejala penyakit menjadi krusial. Deteksi dini terhadap HLB telah dilakukan menggunakan spektrosokopi Vis-NIR (Sankaran et al. 2011) dan spektrosokopi inframerah (Cardinali et al. 2012) tetapi hasil akurasi klasifikasi antara daun belum bergejala dan sehat berkisar $80 \%$ sehingga perlu untuk ditingkatkan agar sistem deteksi dini penyakit HLB

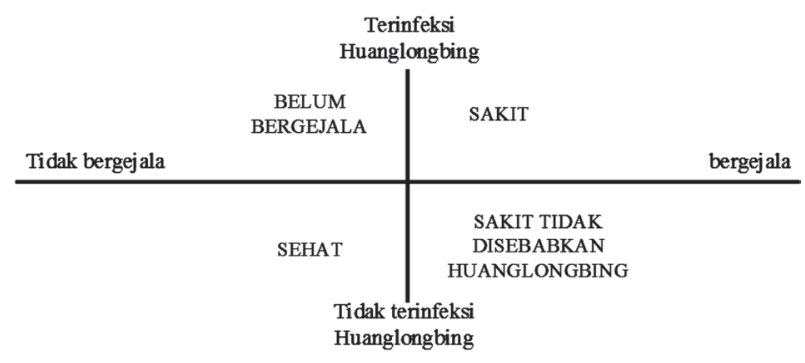

Gambar 1. Ilustrasi istilah untuk jenis sampel yang digunakan. menjadi lebih akurat. Tujuan dari penelitian ini adalah membangun aplikasi deteksi daun terinfeksi HLB menggunakan panjang gelombang terpilih dari pengukuran spektrosokopi Vis-NIR. Hasil penelitian ini diharapkan menjadi metode alternatif deteksi HLB yang lebih cepat, murah dan akurat.

\section{Bahan dan Metode}

\section{Persiapan Sampel}

Sampel daun diperoleh dari kebun jeruk kip (Citrus nobilis) di Situgede, Bogor. Pengambilan sampel dilakukan pada bulan Juni-September 2015. Daun yang digunakan untuk satu set penelitian adalah daun segar yang dipetik pada pagi hari (06.30-08.00 WIB). Tahap awal persiapan sampel diawali survey lapang untuk menentukan pohon jeruk yang memiliki gejala visual HLB dari total 236 pohon. Survey lapang didasarkan pada gejala visual daun berupa blotchy mottle, pucuk daun kuning dan vein corking. Selanjutnya, pohon yang memiliki gejala sesuai kriteria tersebut diuji kandungan pati (Etxeberria et al. 2007). Daun yang bergejala HLB, tepi daun berwarna hitam sedangkan daun yang tidak bergejala HLB tepi daun tidak berwarna. Hasil uji akumulasi pati digunakan untuk menentukan sampel pohon yang perlu diuji dengan metode PCR. Total 15 sampel daun (3-4 helai daun per sampel) diuji dengan metode PCR, sampel tersebut terdiri atas tiga kategori, yaitu daun tidak bergejala HLB, daun dengan gejala HLB dan daun belum bergejala dari pohon yang menunjukkan gejala HLB. Penentuan kategori daun belum bergejala HLB bertujuan untuk menganalisis potensi pendeteksian awal penyakit HLB sebelum gejala morfologi (fisik) muncul karena gejala awal HLB menunjukkan peningkatan kandungan pati, baik pada daun yang menunjukkan gejala fisik atau tidak (Fan et al. 2010). Setiap kategori terdiri atas lima sampel. Hasil uji dengan PCR diperoleh 4 dari 5 sampel daun sehat, 3 dari 5 sampel daun sakit, dan 1 dari 5 sampel daun belum bergejala, positif terinfeksi HLB. Gambar 1 adalah ilustrasi untuk menjelaskan istilah yang digunakan untuk pengkategorian sampel. Salah satu sampel daun sehat terserang penyakit Diplodia (Botryodiplodia theobromae Pat.). selama proses pengujian PCR, sehingga tidak diikutsertakan pada pengukuran spektrum Vis-NIR. Total 7 sampel daun yang dilakukan pengukuran spektrum Vis-NIR. Setiap sampel daun untuk semua pengujian dan pengukuran spektrum disimpan dalam kantong plastik berklip yang di dalamnya terdapat jel silika dan diberi label. Seluruh tahap (pengujian kandungan pati dan PCR serta pengukuran spektrum) dilakukan pada hari yang sama saat pengambilan sampel.

\section{Pengkuran Spektrum}

Total 72 helai daun yang diukur spektrum Vis-NIR, 
yang terdiri atas 32 helai daun sehat, 32 helai daun sakit dan 8 helai daun belum bergejala yang positif HLB berdasarkan uji PCR. Tahap awal sebelum dilakukan pengukuran spektrum, sampel daun dikeringanginkan dan dibersihkan menggunakan tisu kering. Spektrum daun diukur menggunakan spektrometer Vis-NIR (USB2000-VIS-NIR, Ocean Optics, USA) pada rentang panjang gelombang 339-1022nm (resolusi rata-rata $0.33 \mathrm{~nm}$ ). Cahaya bersumber dari lampu tungsten halogen (LS-1, Ocean Optics, USA) yang dilewatkan ke daun dengan metode transmitan, selanjutnya transmisi cahaya tersebut diterima oleh kabel fiber optik dan diteruskan ke spektrometer. Akuisisi, pemprosesan dan kalibrasi spektrum menggunakan perangkat lunak Spectra Suite (Ocean Optics, USA). Data yang digunakan adalah data absorban spektrum setiap pengukuran. Setiap lima kali pengukuran spektrum dilakukan kalibrasi ulang untuk meminimalkan gangguan (noise). Kalibrasi ulang dilakukan dengan pengukuran data intensitas transmisi referensi, yang dalam hal ini intensitas transmisi gelas preparat dan data intensitas gelap.

\section{Analisis Data}

Data spektrum hasil pengukuran spektroskopi Vis-NIR terdiri atas informasi spektrum dan gangguan (noise) sehingga perlu dilakukan praperlakuan data agar terbentuk model kalibrasi yang stabil dan akurat (Cen dan He 2007). Metode praperlakuan yang digunakan antara lain, mean scattering correction (MSC), standart normal variate (SNV), Baseline Correction, turunan pertama dan kedua spektrum. Jenis praperlakuan berbeda tersebut digunakan untuk mendapatkan metode praperlakuan terbaik untuk identifikasi daun sakit HLB.

Seluruh data yang sudah diberikan jenis praperlakuan berbeda dianalisis menggunakan analisis komponen utama (AKU) untuk mengurangi dimensi data dan memvisualkan pengelompokan data. Hasil AKU didapatkan nilai skor komponen utama, nilai loading komponen utama dan explained variance. Pemberian praperlakuan dan analisis komponen utama terhadap spektrum menggunakan perangkat lunak Unscrambler 10.3 (Camo ASA, Oslo, Norway). NIlai loading komponen utama digunakan untuk mendapatkan nilai panjang gelombang sensitif. Explained variance digunakan untuk menjelaskan seberapa banyak komponen utama yang diperlukan untuk menjelaskan keragaman data. Pengklasifikasian menggunakan pendekatan klasifikasi terawasi (supervised classification) dengan metode jaringan saraf tiruan (JST). Pengklasifikasian dengan JST menggunakan neural network toolbox yang tersedia pada MATLAB® 8.3 (The MathWorks Inc., Natick, MA). Data untuk pembangunan model klasifikasi dibagi tiga bagian, data pelatihan, validasi dan pengujian dengan perbandingan 70:15:15, yang pembagiannya dilakukan acak. Jumlah neuron yang digunakan pada lapisan tersembunyi adalah 10 neuron. Pelatihan model JST menggunakan algoritma scaled conjugate gradient backpropagation (trainscg). Fungsi transfer pada lapisan tersembunyi menggunakan fungsi tansig. Fungsi transfer pada lapisan output adalah fungsi softmax. Model klasifikasi dengan JST ditentukan berdasarkan parameter cross entropy (CE) dan akurasi klasifikasi. Cross entropy (CE) adalah fungsi error JST yang menjadi standar pilihan untuk penyelesaian masalah dalam bidang klasifikasi (Granitto et al. 2002). Penggunaan CE sebagai fungsi error dapat mempercepat konvergensi (Yuan et al. 2003) dan memberikan kinerja JST yang baik dibandingkan dengan fungsi kinerja mean square error (MSE) (Nasr et al. 2002). Oleh karena itu, semakin kecil nilai CE semakin baik kinerja model JST tersebut dan semakin tinggi nilai akurasi menujukkan bahwa model JST memiliki kinerja yang baik dalam proses klasifikasi. Metode JST digunakan untuk dua kali proses klasifikasi, pertama untuk mendapatkan jenis praperlakuan yang tepat dengan input nilai skor komponen utama yang dihasilkan dari AKU. Kedua, JST digunakan untuk mendapatkan set panjang gelombang sensitif terbaik dengan memperhatikan nilai kinerja JST

\section{Pembangunan Aplikasi Deteksi Daun Terinfeksi HLB}

Model klasifikasi dari panjang gelombang sensiif terbaik ditanamkan pada aplikasi berbasis komputer desktop yang dikembangkan dengan bahasa pemograman visual basic. Model klasifikasi

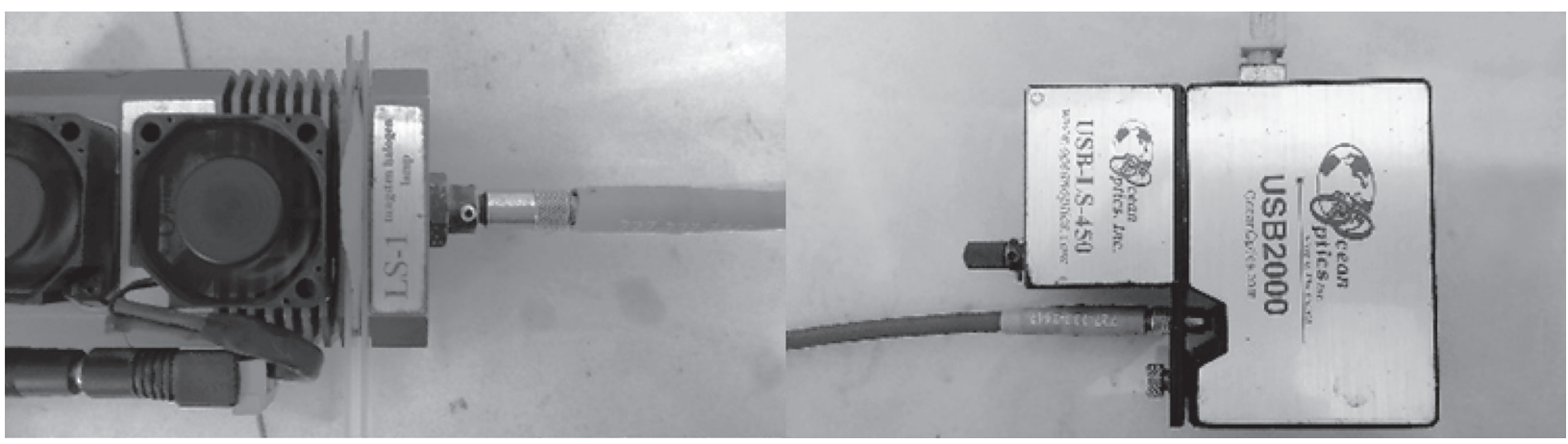

Gambar 2. Posisi pengukuran spektrum daun (kiri) dan spectrometer Vis-NIR (kanan). 
Tabel 1. hasil analisis komponen utama dan klasifikasi menggunakan JST.

\begin{tabular}{lccc}
\hline \multicolumn{1}{c}{ Jenis praperlakuan } & kinerja (cross entropy) & Akurasi (\%) & Jumlah KU \\
\hline No pretreatment & $4.96 \times 10^{-7}$ & 100 & 3 \\
MSC & $1.12 \times 10^{-6}$ & 100 & 3 \\
Turunan spektrum pertama & 0.0796 & 98.4 & 7 \\
Turunan spektrum kedua & 0.0302 & 98.4 & 10 \\
Baseline correction & $1.10 \times 10^{-6}$ & 100 & 3 \\
SNV & $9.30 \times 10^{-7}$ & 100 & 3 \\
\hline
\end{tabular}

yang ditanamkan adalah nilai bobot lapisan input, bias lapisan input, bobot lapisan output dan bias lapisan ouput, yang diperoleh dari metode JST menggunakan input panjang gelombang sensitif terbaik. Pembangunan aplikasi harus memenuhi kritera dapat membaca format file txt, yang merupakan hasil keluaran dari spectrometer VisNIR

\section{Hasil dan Pembahasan}

\section{Karakteristik Spektrum Daun Jeruk}

Hasil pengukuran spektrum daun (64 sampel) tersaji pada Gambar 3. Rentang panjang gelombang 500-1000nm dipilih karena memiliki gangguan yang minimal dibandingkan dengan rentang panjang gelombang 399-499nm dan 1001-1022nm. Spektrum daun sehat memiliki puncak pada panjang gelombang 660nm sedangkan spektrum daun sakit memiliki dua puncak, di panjang gelombang $660 \mathrm{~nm}$ dan 675nm. Puncak spektrum tersebut menyatakan bahwa daun menyerap lebih banyak gelombang cahaya pada panjang gelombang tersebut. Absorban pada beberapa sampel daun sakit memiliki nilai yang lebih rendah dibandingkan dengan absorban daun sehat, tetapi beberapa spektrum daun sakit memiliki nilai absorban yang berhimpit dengan absorban daun sehat. Nilai absorban daun sakit di daerah panjang gelombang cahaya tampak (500-700nm) lebih rendah dibandingkan dengan daun sehat akibat perubahan pigmen yang terjadi di daun. Penyerapan cahaya pada daerah panjang gelombang tersebut, erat kaitannya dengan konsentrasi pigmen yang terdapat di daun, perubahan pigmen sendiri berkaitan erat

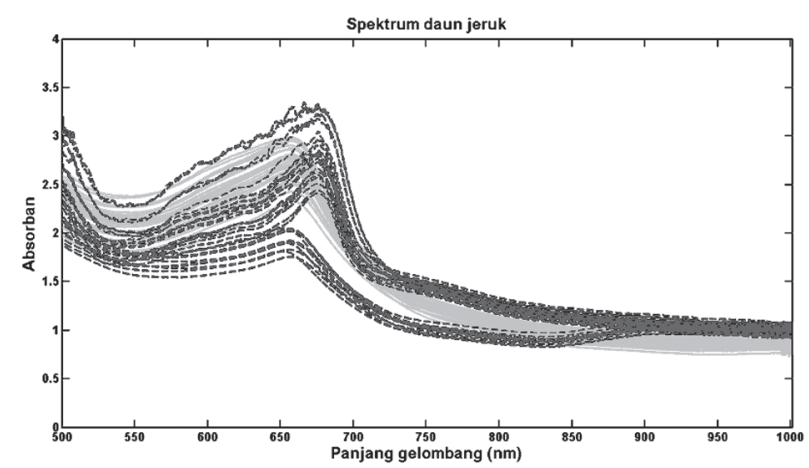

Gambar 3. spektrum daun jeruk sehat dan sakit. dengan status fisiologi tanaman (Sims dan Gamon 2002). Pada daerah panjang gelombang NIR (701$1000 \mathrm{~nm})$, spektrum daun sehat lebih rendah nilai absorbannya dibandingkan dengan daun sakit. Hal tersebut konsisten dengan hasil penelitian lain yang juga menggunakan tehnik spektroskopi VisNIR (Poole 2008; Mishra et al. 2012). Perbedaan nilai absorban di daerah panjang gelombang NIR menunjukkan adanya perubahan kandungan kimia di daun karena rentang daerah panjang gelombang tersebut berkaitan dengan struktur internal dan bahan kering pada daun (Ceccato et al. 2001). Panjang gelombang NIR (701-1000nm) memiliki nilai absorban yang rendah karena hamburan yang terjadi antara udara dan sel pada jaringan daun (West et al. 2003) sehingga sulit untuk menentukan jenis kandungan kimia yang berubah pada daun terinfeksi HLB.

\section{Analisis Data Spektrum Menggunakan Analisis Komponen Utama}

Tahap awal, data spektrum yang tersaji pada Gambar 3 perlu dilakukan praperlakuan untuk mengurangi gangguan yang masih terdapat pada spektrum daun. Nilai akurasi klasifikasi tersaji pada Tabel 1 menunjukkan jenis praperlakuan dengan MSC, SNV dan baseline correction tepat mengklasifikasi spektrum daun sakit dan sehat. Walaupun nilai kinerja dan akurasi klasifikasi data spektrum tanpa praperlakuan sama baiknya dengan tiga perlakuan tadi, pemberian praperlakuan terhadap data spektrum bertujuan untuk meminimalkan terjadinya gangguan, memperbaiki variasi baseline, meningkatkan resolusi spektra dan menormalisasi data (Ozaki et al. 2007) karena gangguan dapat bersumber dari beberapa faktor yaitu, interaksi antar senyawa, bauran cahaya, proses pengukuran spektrum yang kurang baik dan distorsi spektrum akibat peranti keras spectrometer (Heise dan Winzen 2002). Plot skor komponen utama (Gambar 4) menunjukkan bahwa dengan pemberian praperlakuan (MSC, SNV, dan baseline correction), pengelompokkan data lebih baik dibandingkan dengan tanpa praperlakuan. Pada plot skor tersebut (Gambar 4) sampel terbagi menjadi tiga bagian dengan batas antar kelompok jelas. Hasil pengelompokkan berdasarkan plot skor komponen utama tersebut tidak dapat dinyatakan secara kuantitatif (Li dan He 2008). Oleh karena 
Tabel 2. Panjang gelombang sensitif setiap metode praperlakuan.

\begin{tabular}{|c|c|c|c|c|c|c|}
\hline \multirow{2}{*}{$\begin{array}{l}\text { Metode Praperlakuan } \\
\text { MSC }\end{array}$} & \multicolumn{6}{|c|}{ Panjang gelombang (nm) } \\
\hline & 500.52 & 527.62 & 527.62 & 631.91 & 680.8 & 691.21 \\
\hline SNV & 500.52 & 527.62 & 631.91 & 680.8 & 690.87 & 731.79 \\
\hline Baseline correction & 500.52 & 538.61 & 658.16 & 680.8 & 725.84 & 997.25 \\
\hline
\end{tabular}

itu diperlukan metode JST untuk mengklasifikasian sampel sehat dan sakit secara kuantitiaf. Jumlah komponen utama (KU) pada Tabel 1 diperoleh dari nilai explained variance, nilai ini berguna untuk mengetahui berapa banyak komponen utama yang diperlukan untuk menjelaskan keberagaman data. Jumlah komponen utama tiga jenis praperlakuan (MSC, SNV dan baseline correction) paling sedikit diantara jenis praperlakuan lain, hasil ini menunjukkan bahwa dengan tiga jenis praperlakuan tersebut keberagaman data dapat diwakilkan cukup dengan tiga komponen utama dengan nilai akumulasi explained variance mendekati $99 \%$.

Jumlah komponen utama dari tiga jenis praperlakuan digunakan untuk mendapatkan panjang gelombang sensitif pengklasifikasi data spektrum daun sakit dan sehat melalui nilai $X$-loading komponen utama. Gambar 5 menyajikan plot $X$-loading dari tiga jenis praperlakuan. Panjang gelombang sensitif diperoleh dari nilai positif dan negatif tersebesar dari setiap $X$-loading komponen utama (Pholpho et al. 2011), nilai tersebut menunjukkan bahwa panjang gelombang sensitif terpilih berperan penting dalam pengklasifian daun sakit dan sehat. Tabel 2 menunjukkan bahwa panjang gelombang sensitif di daerah cahaya tampak lebih dominan dibandingkan dengan panjang gelombang daerah NIR untuk pengklasifikasian daun sakit dan sehat. Kondisi sampel daun yang bergejala blotchy mottle (warna daun sebagian kuning, hijau, dengan beberapa corak kuning, hijau pucat dan hijau gelap, yang warna tersebut saling bercampur tanpa ada batasan antar corak) berpengaruh terhadap spektrum di daerah cahaya tampak. Panjang gelombang sensitif di daerah NIR $(725.84,731.79$, $997.25 \mathrm{~nm}$ ) berperan dalam pengklasifikasian yang berkaitan dengan perbedaan komposisi kimia pada daun. Keuntungan dari penggunaan beberapa panjang gelombang dibandingkan dengan seluruh panjang gelombang dapat meningkatkan proses deteksi daun terinfeksi huanglongbing (Sankaran dan Ehsani 2011), menghemat waktu analisis (Luo et al. 2012) dan meningkatkan correlation robustness (Rady dan Guyer 2015)

\section{Pengklasifikasian Menggunakan Panjang Gelombang Sensitif}

Panjang gelombang sensitif yang didapatkan dengan menggunakan jenis praperlakuan berbeda memiliki beberapa panjang gelombang sensitif yang sama. Oleh karena itu, dibuat dua dataset baru selain panjang gelombang sensitif dari tiap jenis praperlakuan yang terdiri atas panjang gelombang sensitif yang sama dari tiga praperlakuan dan gabungan panjang gelombang sensitif tiga jenis praperlakuan. Total lima dataset baru tersebut
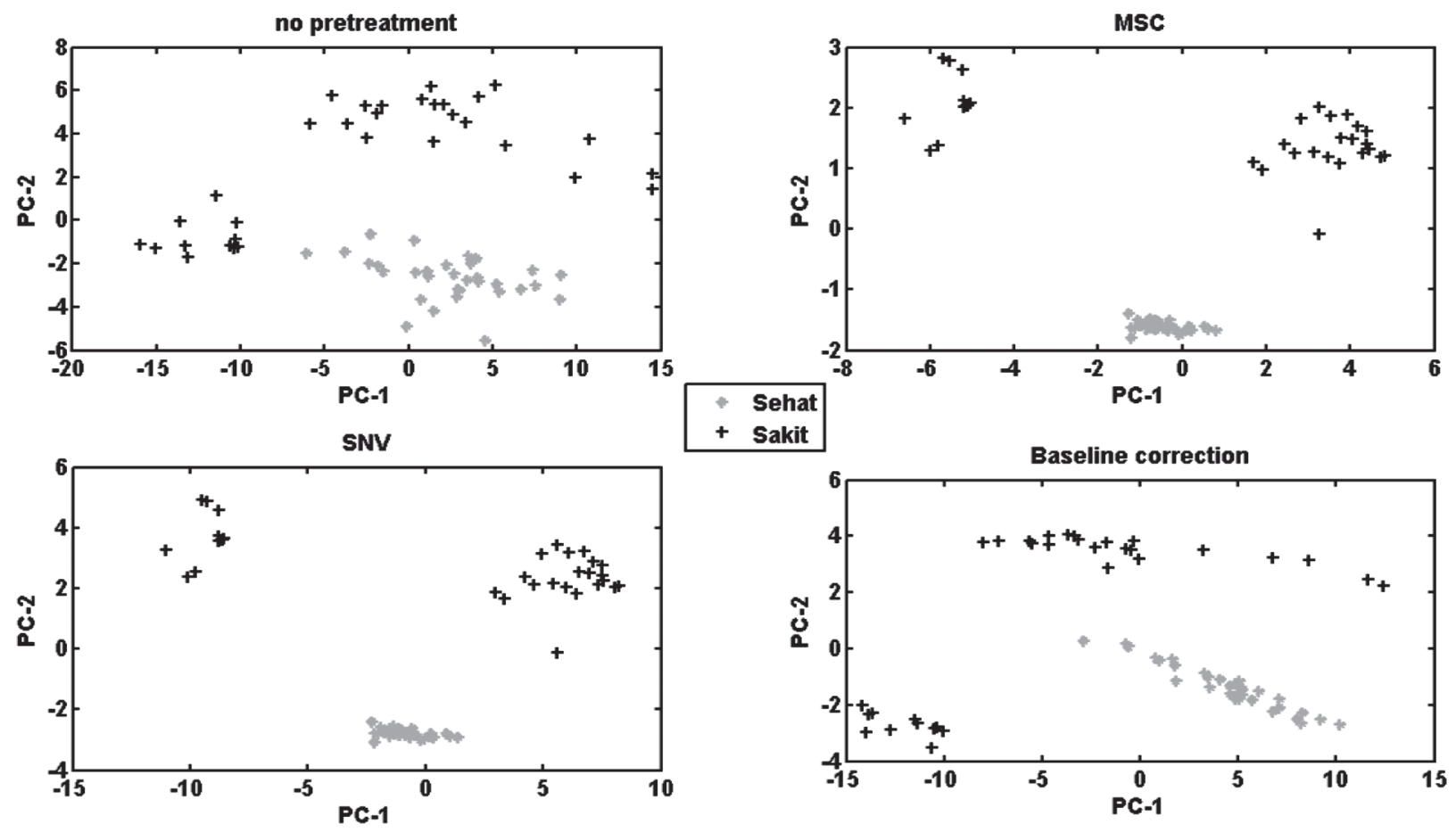

Gambar 4. plot skor komponen utama no pretreatment, MSC, Baseline correction, SNV. 
Tabel 3. hasil klasifikasi JST menggunakan panjang gelombang sensitive.

\begin{tabular}{lcc}
\hline \multicolumn{1}{c}{ Dataset } & Akurasi Klasifikasi (\%) & Kinerja (Cross Entropy) \\
\hline Baseline Correction & 100 & $4.9 \times 10^{-7}$ \\
All data & 100 & $5.32 \times 10^{-7}$ \\
Same data spectrum & 100 & $2.27 \times 10^{-6}$ \\
SNV & 100 & $1.54 \times 10^{-6}$ \\
MSC & 100 & 0.000584 \\
\hline
\end{tabular}

digunakan untuk proses klasifikasi agar didapatkan model klasifikasi terbaik. Hasil klasifikasi menggunakan panjang gelombang sensitif tersaji pada Tabel 3. Berdasarkan nilai kinerja cross entropy dari jaringan saraf tiruan didapatkan bahwa panjang gelombang sensitif dengan praperlakuan baseline correction adalah yang terbaik.

Berdasarkan nilai akurasi dan kinerja JST dari Tabel 3, praperlakuan baseline correction menghasilkan akurasi tertinggi dan nilai kinerja yang paling rendah. Panjang gelombang sensitif dari praperlakuan baseline correction selanjutnya diuji menggunakan data spektrum yang tidak diikutkan selama proses pembangunan model klasifikasi daun jeruk. Data uji (8 sampel) yang digunakan adalah daun dengan kategori belum bergejala dari pohon yang positif terserang HLB. Model klasifikasi mengklasifikasi semua sampel uji sebagai daun sakit (Tabel 4), hasil tersebut konsisten dengan hasil pengujian sampel daun menggunakan metode PCR yang mengkategorikan daun belum bergejala tersebut sebagai daun sakit. Keberhasilan model mengklasifikasi daun belum bergejala dapat terjadi karena diantara panjang gelombang sensitif tersebut terdapat panjang gelombang 680nm yang menunjukkan daerah serapan klorofil (Carter dan Knapp 2001). Hasil penelitian Windham et al. (2011) menyimpulkan bahwa perbedaan antara daun sakit HLB dan daun sehat dapat diamati pada panjang gelombang yang berasosiasi dengan serapan klorofil, yang pada daun sakit HLB memiliki nilai absorban yang lebih rendah dibandingkan dengan daun sehat. Selain panjang gelombang $680 \mathrm{~nm}$, panjang gelombang 997.25nm yang merupakan kisaran panjang gelombang daerah serapan pati (Osborne et al. 1993) juga menjadi pembeda untuk daun sakit dan sehat. Kaitan antara daun sakit terinfeksi HLB dan kandungan pati di daun adalah kandungan pati di daun 3-8 kali lebih banyak dibandingkan dengan daun sehat (Fan et al. 2010). Hasil pengujian terhadap kategori sampel daun belum bergejala menunjukkan bahwa model klasifikasi berpotensi untuk digunakan mendeteksi lebih awal penyakit HLB sehingga tindakan pengendalian dapat dilakukan dengan cepat.

\section{Aplikasi Untuk Deteksi Penyakit HLB}

Aplikasi yang telah dikembangkan berbasis komputer dekstop yang tidakmemerlukan kebutuhan sistem operasi tertentu. Output aplikasi ini berupa keputusan dalam bentuk biner, bahwa data spektum yang diinputkan terklasifikasi sebagai kelompok sakit atau sehat. Aplikasi ini memiliki kelebihan dapat mendeteksi daun jeruk yang terserang HLB walaupun secara morfologi (fisik) belum menunjukkan gejala sakit. Fitur utama dari aplikasi tersaji pada Gambar 6, terdiri atas tombol open, transfer, dan classify, textbox untuk menampilkan
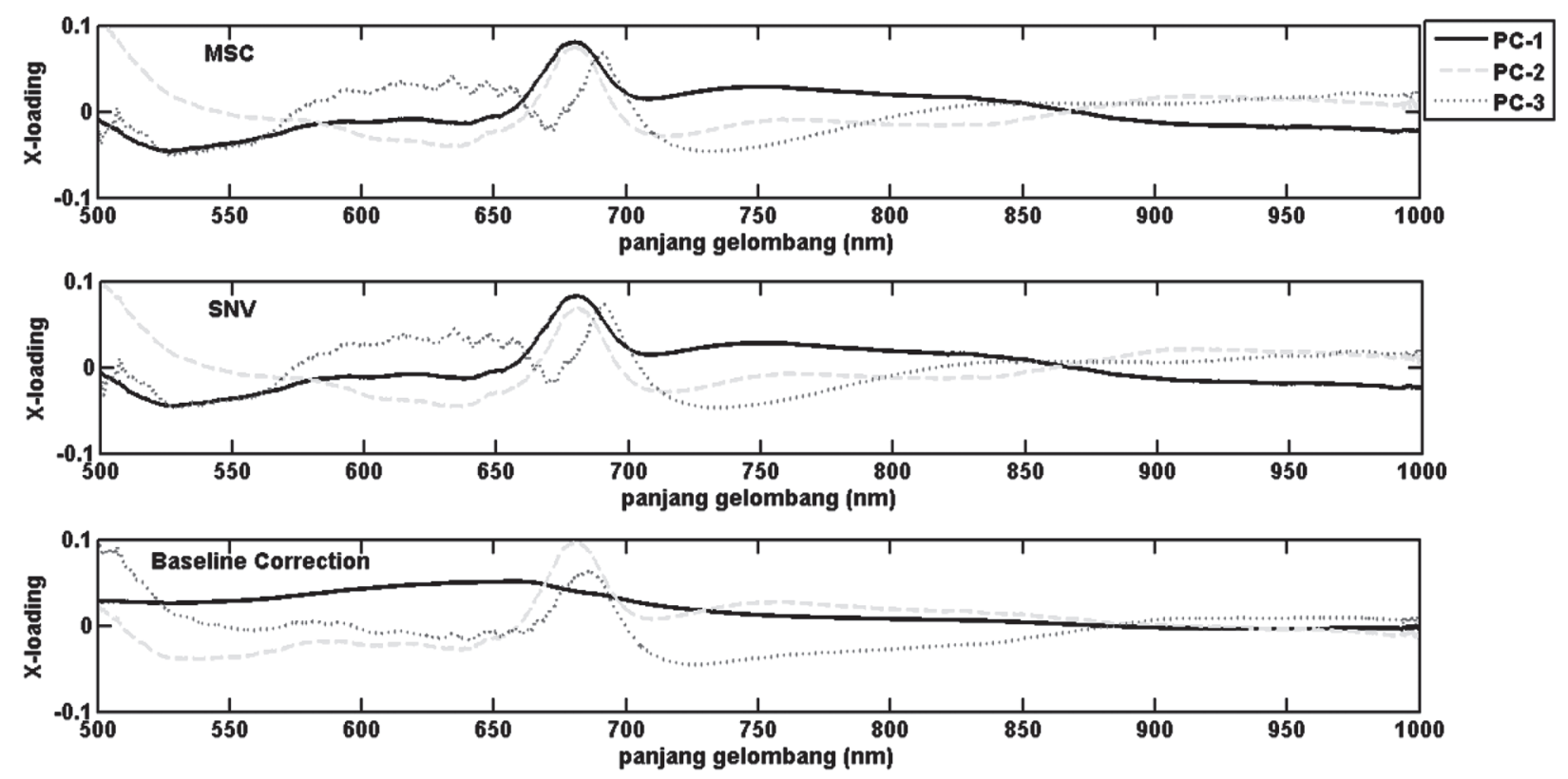

Gambar 5. Plot X-loading komponen utama untuk tiga jenis metode praperlakuan. 
Tabel 4. Hasil klasifikasi JST terhadap spektrum

\begin{tabular}{cccll}
\hline Sampel & \multicolumn{2}{c}{ Aktual } & \multicolumn{2}{l}{ Target } \\
\hline 1 & $1.01 \times 10^{-4}$ & 0.999899 & 0 & 1 \\
2 & $3.45 \times 10^{-6}$ & 0.999997 & 0 & 1 \\
3 & $2.72 \times 10^{-8}$ & 1.000000 & 0 & 1 \\
4 & $9.67 \times 10^{-5}$ & 0.999903 & 0 & 1 \\
5 & $1.79 \times 10^{-5}$ & 0.999982 & 0 & 1 \\
6 & $5.93 \times 10^{-6}$ & 0.999994 & 0 & 1 \\
7 & $3.88 \times 10^{-8}$ & 1.000000 & 0 & 1 \\
8 & $3.51 \times 10^{-3}$ & 0.996494 & 0 & 1 \\
\hline
\end{tabular}

Keterangan: [0 1] kodifikasi untuk kategori sakit

[1 0] kodifikasi untuk kategori sehat

data pengukuran spektrum Vis-NIR, textbox2 untuk menampilkan hasil perhitungan, berupa keputusan bahwa spektrum hasil pengukuran dikategorikan sakit atau sehat, serta listview untuk menampilkan data pengukuran berformat numerik. Setiap tombol panel memiliki fungsi yaitu, tombol open digunakan untuk membuka file hasil pengukuran spectrometer Vis-NIR, kemudian data spektrum ditampilkan pada textbox. Selanjutnya, untuk memisahkan data antara tipe numerik dan tipe karakter dari data pengukuran, digunakan tombol transfer. Tombol classify digunakan untuk proses perhitungan data spektrum Vis-NIR termasuk dalam kelas daun sehat atau sakit, selanjutnya hasil keputusan klasifikasi ditampilkan pada textbox2. Pengklasifikasian spektrum data pengukuran Vis-NIR didasarkan atas model klasifikasi yang dibangun menggunakan metode JST. Nilai bobot dan bias pada lapisan tersembunyi dan lapisan output yang merupakan penyusun dari model klasifikasi ditanamkan pada aplikasi deteksi penyakit HLB untuk mengklasifikasikan data spektrum Vis-NIR yang diinput pada sistem.

\section{Simpulan}

Aplikasi untuk klasifikasi daun jeruk terinfeksi HLB berbasis komputer desktop berdasarkan daun berlum bergejala.

panjang gelombang sensitif telah berhasil dibangun menggunakan bahasa pemograman visual basic. Model klasifikasi yang dibangun menggunakan metode klasifikasi jaringan saraf tiruan. Aplikasi yang dibangun dapat mengklasifikasikan dengan tepat daun sehat dan daun terinfeksi HLB dengan akurasi $100 \%$, dan dapat mengklasifikasikan dengan tepat daun belum bergejala dengan akurasi $100 \%$. Panjang gelombang sensitif yang ditanamkan pada sistem adalah nilai $X$-loading hasil analisis komponen utama dengan pemberian praperlakuan spektrum baseline correction, yang nilai panjang gelombang sensitifnya adalah 500.52 , $538.61,658.16,680.8,725.84$ dan $997.25 \mathrm{~nm}$.

\section{Daftar Pustaka}

Bove JM, Genomique DR, Pathogene P, Recherche C De, Bordeaux I De, Bourlaux E, Cedex O, Df A, Pereira A, Araraquara P. 2006. HUANGLONGBING: A Destructive, NewlyEmerging, Century-Old Disease of Citrus. J. Plant Pathol. 88(1):7-37.

Cardinali MC do B, Boas PRV, Milori DMBP, Ferreira EJ, Silva MF e, Machado MA, Bellete BS, Silva MF das GF da. 2012. Infrared spectroscopy: A potential tool in huanglongbing and citrus variegated chlorosis diagnosis. Talanta 91:1-6.

Carter GA, Knapp AK. 2001. Leaf optical properties in higher plants: linking spectral characteristics to stress and chlorophyll concentration. Am. J. Bot. 88(4):677-684.

Ceccato P, Flasse S, Tarantola S, Jacquemoud S, Gregoire JM. 2001. Detecting vegetation leaf water content using reflectance in the optical domain. Remote Sens. Environ. 77(1):22-33.

Cen H, He Y. 2007. Theory and application of near infrared reflectance spectroscopy in determination of food quality. Trends food Sci. Technol. 18(2):72-83.

Etxeberria E, Gonzalez P, Dawson W, Spann T. 2007. An lodine-Based Starch Test to Assist in Selecting Leaves for HLB Testing.

Fan J, Chen C, Brlansky RH, Gmitter FG, Li ZG. 2010. Changes in carbohydrate metabolism

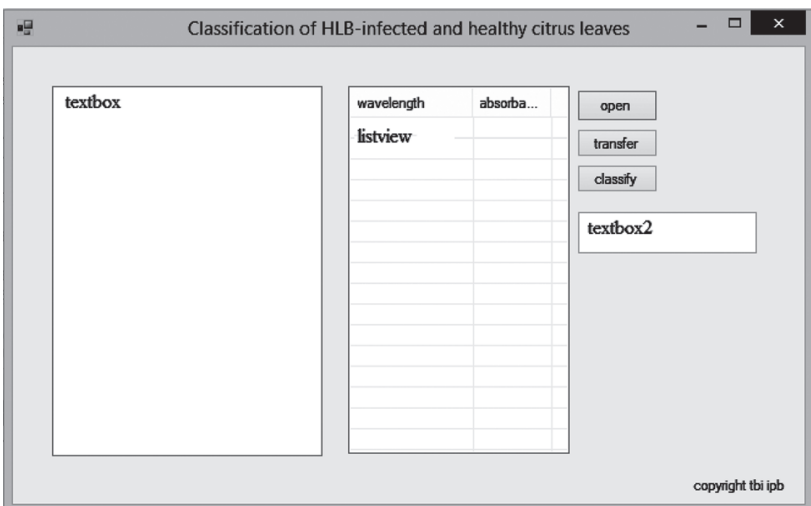

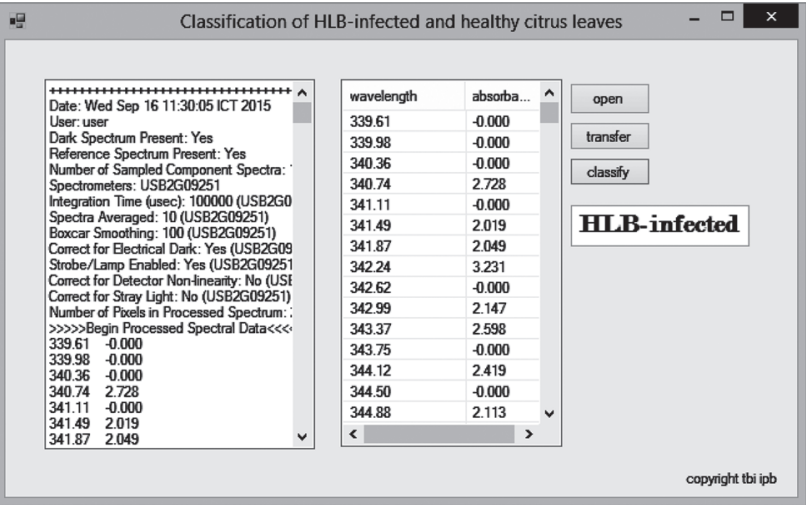

Gambar 6. GUI aplikasi deteksi penyakit HLB, jendela utama (kiri) dan hasil (kanan). 
in Citrus sinensis infected with "Candidatus Liberibacter asiaticus”. Plant Pathol. 59(6):10371043.

Granitto PM, Navone HD, Verdes PF, Ceccatto H a. 2002. Weed seeds identification by machine vision. Comput. Electron. Agric. 33(2):91-103.

Heise HM, Winzen R. 2002. Fundamental Chemometric Methods. In: Siesler H., Ozaki Y, Kawata S, Heise H., editors. Near-Infrared Spectroscopy Principles, Instruments, Applications. Weinheim: Wiley-VCH. p. 125162.

Iftikhar Y, Rauf S, Shahzad U, Zahid MA. 2016. Huanglongbing : Pathogen detection system for integrated disease management $-\mathrm{A}$ review. J. Saudi Soc. Agric. Sci. 15(1):1-11.

Kim DG, Burks TF, Schumann AW, Zekri M, Zhao X. 2009. Detection of Citrus Greening Using Microscopic Imaging. CIGR J. XI.

Li X, He Y. 2008. Discriminating varieties of tea plant based on Vis/NIR spectral characteristics and using artificial neural networks. Biosyst. Eng. 99(3):313-321.

Luo X, Takahashi T, Kyo K, Zhang S. 2012. Wavelength selection in vis / NIR spectra for detection of bruises on apples by ROC analysis. J. Food Eng. 109(3):457-466.

Mishra AR, Karimi D, Ehsani R, Lee WS. 2012. Identification of Citrus Greening (HIb) Using a Vis-Nir Spectroscopy Technique. Trans. Asabe 55(2):711-720.

Nasr G, Badr E, Joun C. 2002. Cross Entropy Error Function in Neural Networks: Forecasting Gasoline Demand. FLAIRS Conf.:381-384.

Nurhadi. 2015. PENYAKIT HUANGLONGBING TANAMAN JERUK ( Candidatus Liberibacter asiaticus ): ANCAMAN DAN STRATEGI PENGENDALIAN Huanglongbing Disease ( Candidatus Liberibacter asiaticus ) on Citrus : Threats and Control Strategy. Pengemb. Inov. Pertan. 8(1):21-32.

Osborne BG, Fearn T, Hindle PH, Hindle PT. 1993. Practical NIR Spectroscopy with Applications in Food and Beverage Analysis. Singapore: Longman Scientific \& Technical (Longman food technology).

Ozaki Y, Morita S, Du Y. 2007. Spectral Analysis. In: Ozaki Y, McClure WF, Christy AA, editors. NearInfrared Spectroscopy In Food Science And Technology. New Jersey: Wiley-Interscience. p. 47-72.

Pholpho T, Pathaveerat S, Sirisomboon P. 2011. Classification of longan fruit bruising using visible spectroscopy. J. Food Eng. 104(1):169-172.

Poole G. 2008. Visible/near-infrared spectroscopy for discrimination of HLB-infected citrus leaves from healthy leaves. In: Proc. Intl. Research Conf. on Huanglongbing. St. Paul, Minn: Plant
Management Network. p. 178-180.

Pourreza A, Lee WS, Raveh E, Ehsani R, Etxeberria E. 2014. Citrus Huanglongbing Detection Using Narrow-Band Imaging and Polarized Illumination. Trans. Asabe 57(1):259-272.

Rady A, Guyer D. 2015. Utilization of visible/nearinfrared spectroscopic and wavelength selection methods in sugar prediction and potatoes classification. J. Food Meas. Charact. 9(1):2034.

Sankaran S, Ehsani R. 2011. Visible-near infrared spectroscopy based citrus greening detection: Evaluation of spectral feature extraction techniques. Crop Prot. 30(11):1508-1513.

Sankaran S, Ehsani R. 2012. Detection of Huanglongbing Disease in Citrus Using Fluorescence Spectroscopy. Trans. Asabe 55(1):313-320.

Sankaran S, Ehsani R, Etxeberria E. 2010. Mid-infrared spectroscopy for detection of Huanglongbing (greening) in citrus leaves. Talanta 83:574-581.

Sankaran S, Maja JM, Buchanon S, Ehsani R. 2013. Huanglongbing (citrus greening) detection using visible, near infrared and thermal imaging techniques. Sensors (Basel). 13(2):2117-30.

Sankaran S, Mishra A, Maja JM, Ehsani R. 2011. Visible-near infrared spectroscopy for detection of Huanglongbing in citrus orchards. Comput. Electron. Agric. 77(2):127-134.

Schneider H. 1968. Anatomy of greeningdiseased sweet orange shoots. Phytopathology 58(1):1155-1160.

Sims DA, Gamon JA. 2002. Relationships between leaf pigment content and spectral reflectance across a wide range of species, leaf structures and developmental stages. Remote Sens. Environ. 81(2):337-354.

Taufik M, Khaeruni A, Pakki T. 2010. Deteksi Keberadaan Citrus Vein Phloem Degeneration (CVPD) dengan Teknik PCR ( Polymerase Chain Reaction ) di Sulawesi Tenggara. J. HPT Trop. 10(1):73-79.

West JS, Bravo C, Oberti R, Lemaire D, Moshou D, McCartney HA. 2003. The Potential of Optical Canopy Measurement for Targeted Control of Field Crop Diseases. Annu. Rev. Phytopathol 41(1):593-614.

Windham WR, Poole GH, Park B, Heitschmidt G, Hawkins SA, Albano JP, Gottwald TR, Lawrence KC. 2011. Rapid screening of Huanglongbinginfected citrus leaves by near-infrared reflectance spectroscopy. Trans. ASABE 54:2253-2258.

Yuan HC, Xiong FL, Huai XY. 2003. A method for estimating the number of hidden neurons in feedforward neural networks based on information entropy. Comput. Electron. Agric. 40(1):57-64. 